\title{
A Model for Ground Temperature Estimations and Its Impact on Horizontal Ground Heat Exchanger Design
}

\section{Lu Xing Jeffrey D. Spitler Liheng Li Pingfang Hu}

\begin{abstract}
The ground-source heat pump systems are highly efficient and energy saving. Its main disadvantage is a significantly higher installation cost compared to conventional systems. The length of the ground heat exchanger (GHX) piping, consequently, the first cost, depends on several factors; one key factor is the undisturbed ground temperature estimations. Xing and Spitler model was developed which provides a new set of ground temperature results for GHX design. There are two common methods in United States to be used for ground temperature estimations - ASHRAE Handbook method and ASHRAE district heating manual method. This paper presents the impact of Xing and Spitler model development on the horizontal ground heat exchanger (HGHX) design. An analytical HGHX simulation tool is developed. 12 geographically diverse sites in United States are chosen for the case study. Three different HGHX configurations are investigated. For each site, HGHX design length using the Xing and Spitler model estimated ground temperatures as inputs are compared to design results based on measured ground temperatures; the calculated HGHX design length percentage error are within $\pm 18.9 \%$. The calculated HGHX design length percentage error using the ASHRAE Handbooks results and ASHR AE district heating manual results are within $\pm 38.3 \%$ and $\pm 57.7 \%$ respectively.
\end{abstract}

\section{INTRODUCTION}

With the development of geothermal energy applications, the ground-source heat pump (GSHP) systems are used frequently in commercial, residential and industrial buildings as a type of sustainable heating and cooling systems. At the end of 2014, the installed geothermal heat pump power has been up to 50.2GW across 4.19 million units in buildings in a worldwide range. The annual energy use is $326,848 \mathrm{TJ} /$ year, the energy savings for geothermal energy application equal 29.1 ton of equivalent oil (Lund and Boyd, 2016).

The GSHP system's ground heat exchangers are usually placed in vertical boreholes or horizontal trenches. The drilling cost of the vertical boreholes is high and that is a barrier to system implementation. The excavation fees for horizontal ground heat exchangers (HGHX) installations are relatively lower. To lessen system initial cost, horizontal 
piping is suggested for buildings located in large land areas and without ground space limitations. What's more, it is required to develop an accurate procedure for sizing such systems. A system that is undersized may lead to equipment failure, while an oversized system is often inefficient and unnecessarily expensive.

Many models have been developed to simulate the GSHP systems or to calculate the required HGHX lengths. These models can be mainly classified as: numerical models and analytical models. Metz (1983) developed a 2-D numerical model to solve the underground heat flow of a buried tank. Mei and Emerson (1985) created a model to simulate double pipes, where the soil moisture freezing around a single pipe and interferences between pipes are considered. Piechowski $(1996 ; 1999)$ presented a 3-D model which calculates the heat conduction problem of multiple pipes, and where moisture transport is considered. He assumed no thermal interference between pipes. Demir et al. (2009) developed a 2-D model considering the effect of snow cover rather than moisture transportation.

Numerical models consider several factors that affect the HGHX performance, they give accurate solutions and are good for theoretical analysis, but need extensive computational time (Florides, et al. 2013). The analytical method is commonly used for designing the HGHX. Ingersoll and Plass (1948) obtained the temperature field around an infinitely long line heat source/sink in an infinite soil domain. Hart and Couvillion (1986) obtained a time-dependent temperature distribution around multiple pipes by superimposing single line source. Persson and Claesson (2005) calculated the temperature distribution of multiple pipes buried in a semi-infinite soil domain, by using the multipoles method combined with the line source approach. Saastamoinen (2007) solves the unsteady state temperature fields due to several constant line sources in ground, by using integral transform method.

In order to design the HGHX using these analytical methods, knowledge of the undisturbed temperatures is required. Accurately determined values of undisturbed ground temperatures, at the depths and time of occurrence, are significantly beneficial for proper sizing of ground heat exchangers and ground source heat pump system as a whole (Kurevija, et al. 2011). This study mainly discusses the application of a simplified model developed by Xing and Spitler (Xing and Spitler 2016a, Xing and Spitler 2016b, Xing et al. 2016) for ground temperature estimations. The calculated ground temperatures are used as input data to the HGHX design model so as to study the simplified model impact on the HGHX piping design.

\section{METHODOLOGIES}

An analytical model for simulating GSHP systems using HGHX has been developed. A typical residential building is built in twelve locations in United States. Building heating and cooling loads, ground temperatures and ground thermal properties are used as inputs to the analytical HGHX model. For each site, the required HGHX lengths are calculated using four ground temperatures results: measured data, Xing and Spitler model results, ASHRAE Handbooks method results and ASHRAE district heating manual method results. The designed HGHX lengths using the three estimated ground temperature results are compared to the designed lengths using measured ground temperatures. The HGHX design length percentage error are summarized and analyzed so as to observe the relationship of ground temperature estimation errors and HGHX design length percentage error.

\section{Simulation of Horizontal Ground Heat Exchangers}

The HGHX simulation tool is developed based upon the foundation heat exchanger (FHX) simulation tool 
(Xing et al. 2012). The FHX simulation tool uses analytical method modeling FHX pipes buried in a semi-infinite soil domain and are connected to indoor heat pumps for building heating and cooling purposes. Each FHX pipe is treated as a line source or sink, multiple ones are simulated based on superposition of a single one. The analytical model assumes that, in the soil, conduction heat transfer is important; moisture transport and freezing effects are neglected. It assumes that the effect of changing weather conditions can be accounted with inputs of undisturbed ground temperatures. With other inputs such as FHX configuration and properties, soil properties, heat pump performance parameters, etc., the simulation tool calculates the FHX pipe lengths required for the house. The simulation tool has been validated against one year hourly time step experimental data collected by Oak Ridge National Lab at a house in Oak Ridge, Tennessee (Xing et al. 2012).

The foundation heat exchanger is a relatively new type of ground heat exchanger that utilizes the excavation often made for basements and foundation in order to reduce the high cost of trench excavation. HGHX is similar to FHX in geometry, without the presence of a basement in close proximity to the heat exchanger tubing. Therefore, the foundation assumed in the foundation heat exchanger simulation tool is removed in order to simulate the horizontal ground heat exchangers.

\section{Heating and Cooling Loads for Prototype Houses}

The HGHX simulation model requires monthly average and peak building loads as inputs. This study involved developing hourly building loads for a prototype house located at twelve different sites in United States. The monthly time step simulation model simplifies the hourly loads, which are treated as monthly constant loads applied over the whole month and monthly peak loads applied at the end of the month (Cullin and Spitler 2011).

House Description: The prototype house used in this study is a single-family residence and is modeled in the EnergyPlus Environment (Crawley et al. 2001). It has a floor area of $148 \mathrm{~m}^{2}\left(1590 \mathrm{ft}^{2}\right)$ and an aspect ratio of 1.56 . The house is maintained at set points of $24.5^{\circ} \mathrm{C}\left(76^{\circ} \mathrm{F}\right)$ in cooling and $21.7^{\circ} \mathrm{C}\left(71^{\circ} \mathrm{F}\right)$ in heating.

Table1. Twelve Parametric Study Sites

\begin{tabular}{cccl}
\hline $\begin{array}{c}\text { States in the } \\
\text { U.S }\end{array}$ & Sites Name (SCAN) & $\begin{array}{c}\text { Köppen-Geiger } \\
\text { climate } \\
\text { classification }\end{array}$ & TMY weather files \\
\hline \hline Arizona & Walnut Gulch & $\mathrm{BSk}$ & Douglas-Bisbee Douglas International Airport \\
Colorado & Nunn & $\mathrm{BSk}$ & Greeley-Weld County AWOS \\
New Mexico & Los Lunas PMC & BSk & Albuquerque International Airport \\
Oregon & Lyn Hart Ranch & $\mathrm{Csb}$ & Klamath Falls International Airport \\
Alabama & WTARS & $\mathrm{Cfa}$ & Huntsville International Airport -Jones Field \\
Arkansas & UAPB Lonoke Farm & $\mathrm{Cfa}$ & Little Rock-Adams Field \\
Georgia & Watkinsville & $\mathrm{Cfa}$ & Athens-Ben Epps Airport \\
Kentucky & Mammoth Cave & $\mathrm{Cfa}$ & Bowling Green-Warren County \\
Maryland & Powder Mill & $\mathrm{Cfa}$ & Baltimore-Washington International Airport \\
Oklahoma & Fort Reno & $\mathrm{Cfa}$ & Oklahoma City-Will Rogers World Airport \\
South Carolina & Pee Dee & $\mathrm{Cfa}$ & Florence Regional Airport \\
Virginia & Tide Water AREC & $\mathrm{Cfa}$ & Franklin Municipal Airport \\
\hline
\end{tabular}

Locations: Twelve sites are chosen over a range of weather conditions. Site names and states for their location are presented in Table 1. These sites are classified to different climates based on the Köppen -Geiger climate classification system (Kottek et al. 2006). Measured Typical Meteorological Year (TMY) weather data are available 
for the sites. These are used as inputs to the Energy Plus house model.

\section{Ground Temperatures, Soil Properties and Others}

Ground temperatures are required as inputs to the HGHX simulation tool. Four sets of ground temperatures are used for calculating HGHX lengths; these are: measured ground temperatures, Xing and Spitler model results and two commonly used approaches calculation results.

Measurements: The Soil Climate Analysis Network (SCAN) provides ground temperature data at the twelve sites at four depths: $5 \mathrm{~cm}, 20 \mathrm{~cm}, 50 \mathrm{~cm}$ and $100 \mathrm{~cm}$ (2in, 8in, 20in and 40in) for 3-8 years inside United States (NRCS 2013). For each site, these results are averaged and compiled into a typical year ground temperature file. At these sites, ground temperature measurements are available to the $100 \mathrm{~cm}$ (40in) depth. Ground temperatures varies at different depths and time of year, and they are not linearly related. To obtain the "measured" ground temperatures at the HGHX burial depths during certain time frame, the measured ground temperatures are represented into a two-harmonic model (Xing 2014). Lord Kelvin (Thomson 1862) presented a higher order harmonic model. At the order of two, it becomes a two-harmonic model with five parameters - annual average ground temperature, two annual temperature amplitude at the ground surface and the two phase lag. These measured results are the "best" ground temperatures can be achieved using a two-harmonic relationship even if the measurement data are available.

Xing and Spitler Model: Measured ground temperatures are limited, modeling can be a useful tool. Analytical model in an equation form requires much less computational time and is convenient for engineering applications. A simplified analytical model (Xing and Spitler 2016a, Xing and Spitler 2016b, Xing et al. 2016) for undisturbed ground temperature estimation has been developed. The model relies on five weather-related constants - annual average undisturbed ground temperature, two annual amplitudes of surface temperature variations and two phase angles to predict the ground temperatures. Automatic procedures have been developed for generating these constant values for 4112 sites or more in a world-wide range. The procedures have been validated using 3-8 years of measured results at nineteen SCAN sites in United States (Xing and Spitler 2016a, Xing and Spitler 2016b, Xing et al. 2016).

ASHRAE Handbook Method: In the U.S., a commonly used approach is the Fourier one-harmonic model (Narasimhan 2010). The model relies on three parameters - annual average ground temperature, annual temperature amplitude at the ground surface and the phase lag to estimate ground temperatures. The annual average ground temperature and annual temperature amplitude at the ground surface can be read from very small maps for the continental US as Figure 17 of Chapter 34 of the ASHRAE Handbook - HVAC Applications (2011) or North America as Figure 13 of Chapter 18 of the ASHRAE Handbook - Fundamentals (2013a). These maps can be traced back to research in the 1920s (Collins 1925) and 1950s (Chang 1958).

ASHRAE District Heating Manual Method: ASHRAE published a district heating guide (ASHRAE 2013b) which also uses one-harmonic model to estimate the undisturbed ground temperatures. The method is developed based on the assumption that the average monthly ground surface temperature equals the average monthly air temperature. This is done for all 5564 weather stations (U.S. and international) listed in Chapter 14 of 2009 ASHRAE Handbook - Fundamentals. These constants are publicly available (ASHRAE, 2013c).

For this study, typical ground thermal properties is assumed. The soil is $60 \%$ saturated clay loam, with thermal 
conductivity of $1.08 \mathrm{~W} / \mathrm{m} \cdot \mathrm{K}\left(0.624 \mathrm{Btu} / \mathrm{ft}^{\circ} \cdot{ }^{\circ} \mathrm{F} \cdot \mathrm{hr}\right)$ and volumetric heat capacity of $2.479 \mathrm{MJ} / \mathrm{m}^{3} \cdot \mathrm{K}\left(36.96 \mathrm{Btu} / \mathrm{ft}^{3}{ }^{\circ}{ }^{\circ} \mathrm{F}\right)$. $3 / 4$ inch diameter HDPE piping is used; two HGHXs are buried in a single trench at $1.5 \mathrm{~m}$ (4.9ft) depths with a distance of $0.6 \mathrm{~m}(2.0 \mathrm{ft})$. The fluid flowing in the tubes is water mixed with $10 \%$ propylene glycol.

\section{Component Sizing}

The HGHX simulation tool allows users to perform HGHX simulation to determine the monthly average and peak fluid temperatures entering the heat pump using building heating and cooling loads, ground temperatures, soil properties and others as inputs. By changing the length of the HGHX pipes, the user can limit the fluid temperature to within heat pump constraints. The constraining temperature for the water to air heat pump is set to be minimum entering fluid temperature $(\mathrm{EFT})$ of $0{ }^{\circ} \mathrm{C}\left(32^{\circ} \mathrm{F}\right)$ and a maximum EFT of $35^{\circ} \mathrm{C}\left(95^{\circ} \mathrm{F}\right)$.

\section{RESULTS ANALYSIS}

For the twelve sites listed in Table 1, the required HGHX lengths are calculated and presented in Table 2. These sites are located in two climates: 4 sites are in arid or dry-summer climates and 8 sites are in warm climates. The HGHXs lengths are calculated using the four sets of ground temperatures previously described.

Table 2: Horizontal Ground Heat Exchanger Design Lengths, m (ft)

\begin{tabular}{|c|c|c|c|c|c|c|c|}
\hline $\begin{array}{l}\text { Climate } \\
\text { zone }\end{array}$ & $\begin{array}{c}\text { States in the } \\
\text { U.S. }\end{array}$ & SCAN site name & $\begin{array}{l}\text { Köppen-Geiger } \\
\text { climate type }\end{array}$ & $\begin{array}{l}\text { Measured } \\
\text { results }\end{array}$ & $\begin{array}{c}\text { Xing and } \\
\text { Spitler model }\end{array}$ & $\begin{array}{c}\text { ASHRAE } \\
\text { Handbooks } \\
\text { method }\end{array}$ & $\begin{array}{c}\text { ASHRAE } \\
\text { district heating } \\
\text { manual } \\
\text { method } \\
\end{array}$ \\
\hline \multirow{4}{*}{$\begin{array}{l}\text { Arid or dry } \\
\text { summer } \\
\text { climates }\end{array}$} & Arizona & Walnut Gulch & BSk & $87.9(288.4)$ & $82.6(271.0)$ & $82.9(272.0)$ & $64.8(212.6)$ \\
\hline & Colorado & Nunn & BSk & $203.4(667.3)$ & $193.4(643.5)$ & $198.4(650.9)$ & $293(961.3)$ \\
\hline & New Mexico & Los Lunas PMC & BSk & $65.9(216.2)$ & $63.1(207.0)$ & $56.4(185.0)$ & $77.1(253.0)$ \\
\hline & Oregon & Lyn Hart Ranch & Csb & $148.4(486.9)$ & $125.7(412.4)$ & $96.5(316.6)$ & $194.1(636.8)$ \\
\hline \multirow{8}{*}{$\begin{array}{l}\text { Warm } \\
\text { climates }\end{array}$} & Alabama & WTARS & Cfa & $79.2(259.8)$ & $83.2(273.0)$ & $82(269.0)$ & $84.7(277.9)$ \\
\hline & Arkansas & UAPB Lonoke Farm & $\mathrm{Cfa}$ & $77.1(253.0)$ & $73.3(240.5)$ & $73.3(240.5)$ & $70.1(230.0)$ \\
\hline & Georgia & Watkinsville & $\mathrm{Cfa}$ & $61.1(200.5)$ & $61.3(201.1)$ & $62.5(205.1)$ & $61.4(201.4)$ \\
\hline & Kentucky & Mammoth Cave & $\mathrm{Cfa}$ & 113.1 (371.1) & $113(370.7)$ & $110.1(361.2)$ & $125.3(411.1)$ \\
\hline & Maryland & Powder Mill & Cfa & $103(337.9)$ & $99.2(325.5)$ & $88.5(290.4)$ & $110.8(363.5)$ \\
\hline & Oklahoma & Fort Reno & Cfa & 87 (285.4) & $79.4(260.5)$ & $76(249.3)$ & $84.6(277.6)$ \\
\hline & South Carolina & Pee Dee & Cfa & $79.6(261.2)$ & $75.6(248.0)$ & $69.2(227.0)$ & $68.2(223.8)$ \\
\hline & Virginia & Tide Water AREC & $\mathrm{Cfa}$ & $65.1(213.6)$ & $63.2(207.3)$ & 59 (193.6) & \\
\hline
\end{tabular}

For each site, the "Xing and Spitler model" result is compared to the "Measured results"; HGHX design length percentage error using Xing and Spitler model estimated ground temperatures is calculated and presented in Table 3. The HGHX design length percentage errors are within the range of $\pm 15.3 \%$. Table 3 also shows the HGHX design length percentage error using ASHRAE Handbooks method and ASHRAE district heating manual method, which are within the range of $\pm 35.0 \%$ and $\pm 44.1 \%$ respectively. It is found out that, using ASHRAE Handbooks methods estimated ground temperatures to design HGHX lengths, in most cases, the error introduced leads to designs with shorter boreholes compared to the reference. In other words, this methods will cause undersizing of HGHX pipes. The ASHRAE District heating manual method gives designed results with sometimes shorter and other times longer boreholes compared to the reference. 
Table 3: HGHX Design length percentage error, \%

\begin{tabular}{|c|c|c|c|c|c|c|}
\hline $\begin{array}{l}\text { Climate } \\
\text { zone }\end{array}$ & $\begin{array}{l}\text { States in the } \\
\text { U.S. }\end{array}$ & SCAN site name & $\begin{array}{l}\text { Köppen-Geiger } \\
\text { climate type }\end{array}$ & $\begin{array}{l}\text { Xing and Spitler } \\
\text { model }\end{array}$ & $\begin{array}{l}\text { ASHRAE } \\
\text { Handbooks } \\
\text { method }\end{array}$ & $\begin{array}{c}\text { ASHRAE District heating } \\
\text { manual } \\
\text { method }\end{array}$ \\
\hline \multirow{4}{*}{$\begin{array}{l}\text { Arid or dry } \\
\text { summer } \\
\text { climates }\end{array}$} & Arizona & Walnut Gulch & BSk & -6.0 & -5.7 & -26.3 \\
\hline & Colorado & Nunn & $\mathrm{BSk}$ & -4.9 & -2.5 & 44.1 \\
\hline & New Mexico & Los Lunas PMC & $\mathrm{BSk}$ & -4.2 & -14.4 & 17.0 \\
\hline & Oregon & Lyn Hart Ranch & $\mathrm{Csb}$ & -15.3 & -35.0 & 30.8 \\
\hline \multirow{8}{*}{$\begin{array}{l}\text { Warm } \\
\text { climates }\end{array}$} & Alabama & WTARS & Cfa & 5.1 & 3.5 & 6.9 \\
\hline & Arkansas & UAPB Lonoke Farm & $\mathrm{Cfa}$ & -4.9 & -4.9 & -9.1 \\
\hline & Georgia & Watkinsville & Cfa & 0.3 & 2.3 & 0.5 \\
\hline & Kentucky & Mammoth Cave & $\mathrm{Cfa}$ & -0.1 & -2.7 & 10.8 \\
\hline & Maryland & Powder Mill & Cfa & -3.7 & -14.1 & 7.6 \\
\hline & Oklahoma & Fort Reno & $\mathrm{Cfa}$ & -8.7 & -12.6 & -2.8 \\
\hline & South Carolina & Pee Dee & Cfa & -5.0 & -13.1 & -14.3 \\
\hline & Virginia & Tide Water AREC & Cfa & -2.9 & -9.4 & \\
\hline
\end{tabular}

\section{Ground Temperature Estimations and HGHX Design length percentage error}

It is found from Table 3, for the twelve sites, that the "Xing and Spitler model" result gives an average of 4.9\% and $10.4 \%$ lower HGHX design length percentage error than the two common methods. At the two sites in Oregon and Colorado, the HGHX design length percentage error using Xing and Spitler model estimated ground temperatures is $19.7 \%$ and $39.2 \%$ lower than the two common used methods respectively. Why is that?

The HGHXs are designed by constraining the heat pump entering fluid temperatures (EFTs) within a range of $0^{\circ} \mathrm{C}-35^{\circ} \mathrm{C}\left(32^{\circ} \mathrm{F}-95^{\circ} \mathrm{F}\right)$. The heat pump EFTs are closely related to peak (annual maximum/minimum) ground temperatures. Therefore, the HGHX design length percentage error is supposed to be correlated to the peak ground temperature estimation error. Figures 1 plots the peak ground temperatures estimation errors versus corresponding HGHX design length percentage error, for the twelve sites. It is observed that the HGHX design length percentage error and peak ground temperature estimation errors are almost linearly correlated.

The Xing and Spitler model gives much lower peak ground temperature estimation errors, less than $1.6^{\circ} \mathrm{C}$ $\left(2.9^{\circ} \mathrm{F}\right)$, circled in a square box in Figure 1. The corresponding HGHX design length percentage error are less than 15.3\%. The ASHRAE Handbooks method and ASHRAE district heating manual method give higher peak ground temperature estimation errors $2.7^{\circ} \mathrm{C}\left(4.9^{\circ} \mathrm{F}\right)$ and $4.7^{\circ} \mathrm{C}\left(8.5^{\circ} \mathrm{F}\right)$. These lead to the higher HGHX design length percentage error, $35.0 \%$ and $44.1 \%$ respectively.

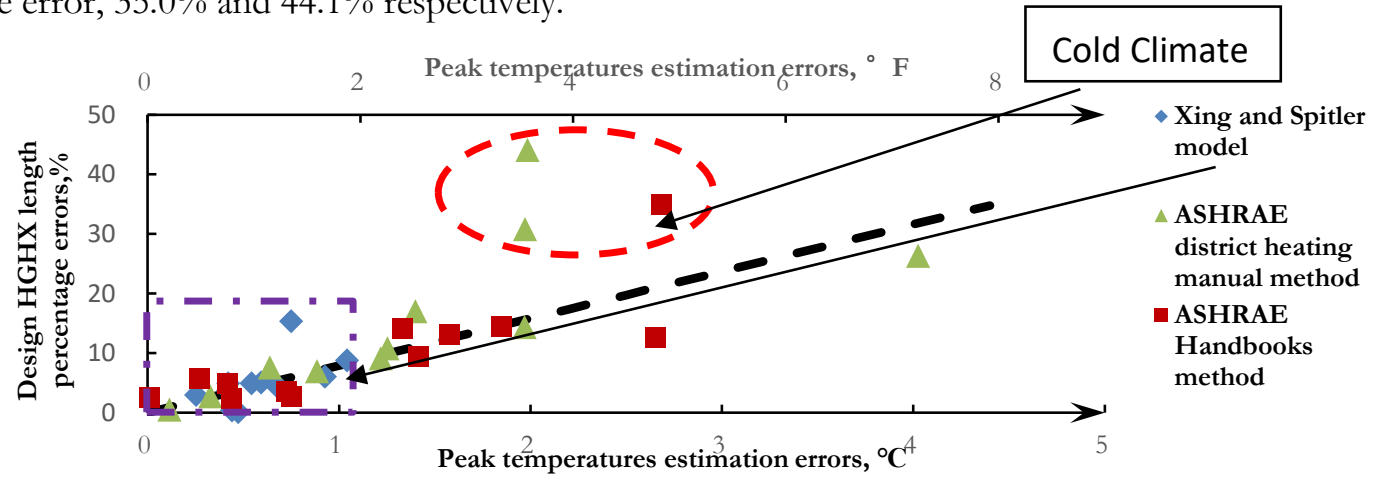

Figure 1 Correlations of peak ground temperature estimation error and HGHX design length percentage error 
At two sites Oregon and Colorado (circled in a round box in Figure 1), data points deviate from the fitting line. These two sites are located in cold climates, where the HGHX lengths required for the system are relatively longer: $148.4 \mathrm{~m}$ and $203.4 \mathrm{~m}$ (486.9ft and 667.3ft). As the HGHX design length increases, the HGHX design length percentage error correspond faster to the increase of the ground temperature estimation error. This suggests that, in colder climates, the accuracy of predicting the ground temperatures is more influential for designing of HGHX.

\section{Pipe Configurations and HGHX Design length percentage error}

One typical type of HGHX configurations (Figure 2a) has been investigated and it is concluded that the ground temperature estimations error have an important effect on HGHX design accuracy. For the twelve parametric study sites, the Xing and Spitler model gives lower ground temperature estimation errors than the two commonly used approaches do. Using the Xing and Spitler model estimated ground temperatures as inputs to HGHX simulation model, the HGHX design length percentage error are greatly reduced. Would similar conclusions be drawn for different HGHX configurations?

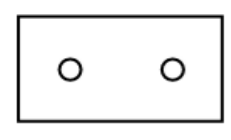

(a)Two pipes in one layer

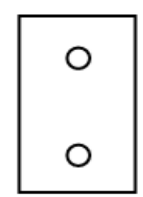

(b) Two pipes in two layers

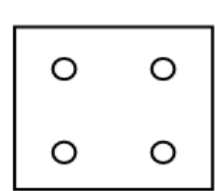

(c)Four pipes in two layers

Figure 2 Three typical HGHX configurations

Figure 2 presents three types of HGHX configurations. These HGHXs are buried at: (a) $1.5 \mathrm{~m}$ (4.9ft) depth, $0.6 \mathrm{~m}(2.0 \mathrm{ft})$ horizontal distance between two pipes (b) $0.9 \mathrm{~m}(3.0 \mathrm{ft})$ and $1.5 \mathrm{~m}(4.9 \mathrm{ft})$ depths (c) $0.9 \mathrm{~m}(3.0 \mathrm{ft})$ and $1.5 \mathrm{~m}$ (4.9ft) depths, $0.6 \mathrm{~m}$ (2.0ft) horizontal distance between two pipes. Table 4 shows the HGHX design length percentage error using the Xing and Spitler model results for these three configurations shown in Figure 2.

Table 4. HGHX Design length percentage error for Three HGHX Configurations, \%

\begin{tabular}{|c|c|c|c|c|c|c|}
\hline Climate zone & States in the U.S. & SCAN site name & $\begin{array}{c}\text { Köppen-Geiger } \\
\text { climate type }\end{array}$ & $\begin{array}{l}\text { Two pipes in one } \\
\text { layer (Figure 2a) }\end{array}$ & $\begin{array}{l}\text { Two pipes in two } \\
\text { layers (Figure 2b) }\end{array}$ & $\begin{array}{l}\text { Four pipes in two } \\
\text { layers (Figure 2c) }\end{array}$ \\
\hline \multirow{4}{*}{$\begin{array}{l}\text { Arid or dry } \\
\text { summer } \\
\text { climates }\end{array}$} & Arizona & Walnut Gulch & BSk & -6.5 & -6.0 & -6.5 \\
\hline & Colorado & Nunn & BSk & -3.6 & -4.9 & -3.7 \\
\hline & New Mexico & Los Lunas PMC & $\mathrm{BSk}$ & -9.2 & -4.2 & -9.1 \\
\hline & Oregon & Lyn Hart Ranch & Csb & -18.9 & -15.3 & -18.9 \\
\hline \multirow{8}{*}{ Warm climates } & Alabama & WTARS & Cfa & 5.9 & 5.1 & 6.0 \\
\hline & Arkansas & UAPB Lonoke Farm & Cfa & -4.9 & -4.9 & -4.9 \\
\hline & Georgia & Watkinsville & Cfa & -1.2 & 0.3 & -1.6 \\
\hline & Kentucky & Mammoth Cave & Cfa & 1.7 & -0.1 & 1.8 \\
\hline & Maryland & Powder Mill & $\mathrm{Cfa}$ & -5.1 & -3.7 & -5.5 \\
\hline & Oklahoma & Fort Reno & Cfa & -8.9 & -8.7 & -9.1 \\
\hline & South Carolina & Pee Dee & $\mathrm{Cfa}$ & -5.3 & -5.0 & -5.4 \\
\hline & Virginia & Tide Water AREC & $\mathrm{Cfa}$ & -2.8 & -2.9 & -2.9 \\
\hline
\end{tabular}

Table 4 results demonstrate that using different HGHX configurations, the HGHX design length percentage error using the Xing and Spitler model results slightly change. The maximum variation is $5 \%$ and occurs in New Mexico. The Xing and Spitler model is used for estimating ground temperature at the HGHX burial depths for a 
certain time frame. When HGHX configurations change, peak ground temperature estimation errors vary. For the three HGHX configurations, the Xing and Spitler model peak ground temperature estimations errors are all less than $1.6^{\circ} \mathrm{C}\left(2.9^{\circ} \mathrm{F}\right)$. The ASHRAE Handbook and the ASHRAE district heating manual estimation errors are less than $2.9^{\circ} \mathrm{C}$ and $5.4^{\circ} \mathrm{C}\left(5.2^{\circ} \mathrm{F}\right.$ and $\left.9.7^{\circ} \mathrm{F}\right)$ respectively. Overall, the Xing and Spitler model gives lower ground temperature estimation errors at different depths and time of year compared to the two common methods. The HGHX design length percentage error is correlated to the peak ground temperature estimation error. Thus, using different HGHX configurations, it still gives relatively lower HGHX design length percentage error.

Figure 3 plots estimated HGHX pipe lengths using Xing and Spitler model results against the estimated HGHX lengths based on measured ground temperatures, for three HGHX configurations and twelve parametric study sites. Ideally, if designed HGHX lengths based on Xing and Spitler model results are identical to the designed value based on measured results, all these data points stay on a $45^{\circ}$ line. Figure 3 shows that percentage errors for eleven sites are in the range of $\pm 9.2 \%$, with one site in the range of $\pm 18.9 \%$. Figure 4(a) and 4(b) plot the HGHX design length percentage error for ASHRAE Handbooks method and ASHRAE DHM method for three configurations: two pipes in one layer, two pipes in two layers and four pipes in two layers. Table 3 presents the designed length errors for two pipes in one layer configuration, the maximum errors are $\pm 35 \%$ and $\pm 44.1 \%$ respectively. For the other two configurations, errors are also calculated, maximum of which are $\pm 38.3 \%$ and $\pm 57.7 \%$ respectively. In Figure 4(a) and 4(b), at site Oregon and site Colorado, when the design HGHX lengths, measured results are at about $99.6 \mathrm{~m}$ and $125.4 \mathrm{~m}$, the design HGHX lengths, ASHRAE Handbook are at about $61.5 \mathrm{~m}$ and the design HGHX lengths, ASHRAE DHM are at about 197.8m. The green triangle dot showing the design percentage error are located on orange line which are $\pm 38.3 \%$ and $\pm 57.7 \%$ off the reference results.

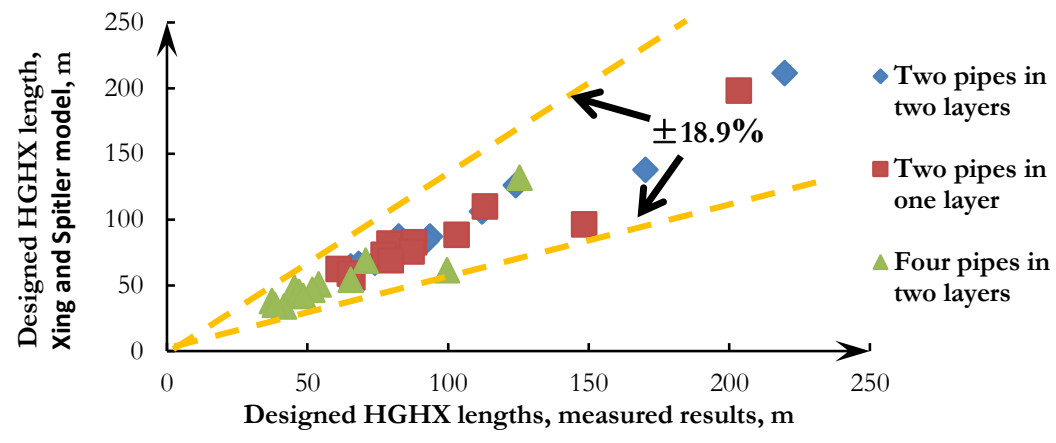

Figure 3 Designed HGHX lengths using Xing and Spitler model estimated ground temperatures

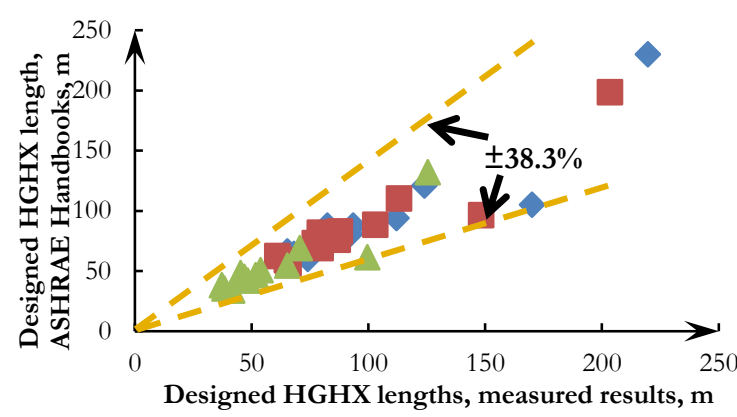

(a) ASHRAE handbook method

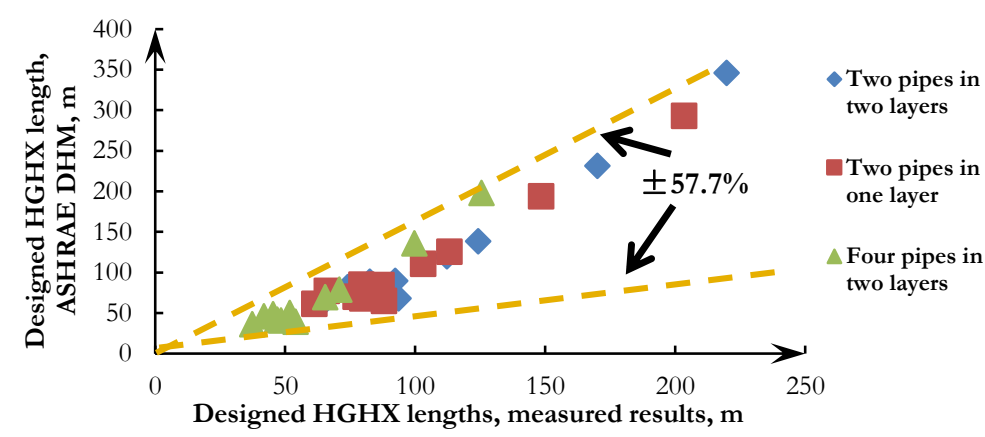

(b) ASHRAE district heating manual method

Figure 4 Designed HGHX lengths using two common methods 


\section{CONCLUSIONS}

This paper discusses the application of Xing and Spitler model 2016 and its impact on improving HGHX design accuracy. This study is performed for twelve locations in the U.S. and three different HGHX configurations are investigated. For each location and each HGHX configuration, the HGHX is designed with: measured ground temperatures, Xing and Spitler model results, two common methods results （ASHRAE Handbooks and ASHRAE district heating manual) . The designed HGHX lengths using the three estimated ground temperatures are compared to the designed lengths using measured results respectively. The HGHX design length percentage error is found to be almost linearly correlated to the peak ground temperature estimation error. For all cases, the Xing and Spitler model estimations errors are less than $1.6^{\circ} \mathrm{C}\left(2.9^{\circ} \mathrm{F}\right)$. ASHRAE Handbook results errors are less than $2.9^{\circ} \mathrm{C}\left(5.2^{\circ} \mathrm{F}\right)$; ASHRAE district heating manual result errors are less than $5.4^{\circ} \mathrm{C}\left(9.7^{\circ} \mathrm{F}\right)$. Corresponding HGHX design length percentage error using the Xing and Spitler model results are within the range of $\pm 18.9 \%$. HGHX design length percentage error using the ASHRAE Handbook results and ASHRAE district heating manual results are within the range of $\pm 38.3 \%$ and $\pm 57.7 \%$ respectively. Application of the Xing and Spitler model helps improving HGHX design accuracy, and lead to a reduced capital cost of the installed GSHP system or promise a well performance of HSHP system.

\section{REFERENCE}

ASHRAE. 2011. ASHRAE Handbook - Heating ventilating and air conditioning applications. Atlanta: ASHRAE.

ASHRAE. 2013a. ASHRAE Handbook - Fundamentals. Atlanta: ASHRAE.

ASHRAE. 2013b. District Heating Guide. Atlanta: ASHRAE.

ASHRAE. 2013c. http://tc62.ashraetcs.org/pdf/ASHRAE_Climatic_Data.pdf.

Chang, J.H. 1958. Ground Temperature. Bluehill Meteorological Observatory, Harvard University.

Collins, W. D. 1925. Temperature of Water Available for Industrial Use in the United States. United States Geological Survey Water Supply Paper 520-F, Washington: USGS.

Crawley, D.B., L.K. Lawrie, F.C. Winkelmann, W.F. Buhl, Y.J. Huang, C.O. Pedersen, R.K. Strand, R.J. Liesen, D.E. Fisher, M.J. Witte, and J. Glazer. 2001. EnergyPlus: Creating a New-Generation Building Energy Simulation Program. Energy and Buildings 33(4): 319-331.

Cullin, J.R. and J.D. Spitler. 2011. A Computationally Efficient Hybrid Time Step Methodology for Simulation of Ground Heat Exchangers. Geothermics. 40(2): 144-156.

Demir, H., A. Koyun, and G. Temir. 2009. Heat Transfer of Horizontal Parallel Pipe Ground Heat Exchanger and Experimental Verification. Applied Thermal Engineering 29: 224-233.

Florides, G., E. Theofanous, I. Iosif-Stylianou, S. Tassou, P. Christodoulides, Z. Zomeni, E. Tsiolakis, S. Kalogirou, V. Messaritis, P. Pouloupatis, and G. Panayiotou. 2013. Modeling and Assessment of the Efficiency of Horizontal and Vertical Ground Heat Exchangers. Energy 58: 655-663.

Hart, D.P., and R. Couvillion. 1986. Earth-Coupled Heat Transfer, National Water Well Association, Dublin, OH. 192.

Ingersoll, L. R., and H. J. Plass. 1948. Theory of the Ground Pipe Heat Source for the Heat Pump. Heating, Piping and Air conditioning 20: 119-122.

Kottek, M., J. Grieser, C. Beck, B. Rudolf, and F. Rubel. 2006. World Map of the Köppen-Geiger Climate Classification Updated. Meteorologische Zeitschrift 15(3): 259-263. 
Kurevija, T., D. Vulin, and V. Krapec. 2011. Influence of Undisturbed Ground Temperature and Geothermal Gradient on the Sizing of Borehole Heat Exchangers. Geothermal Application, Sweden: 8-13.

Lund, W. John, and Tonya L. Boyd. 2016. Direct Utilization of Geothermal Energy 2015 Worldwide Review. Geothermics 60: 66-93.

Mei, V. C., and C. J. Emerson. 1985. New approach for analysis of ground-coil design for applied heat pump systems. ASHRAE Journal 91(2): 1216-1224.

Metz, P. D. 1983. A Simple Computer Program to Model Three-Dimensional Underground Heat Flow With Realistic Boundary Conditions. Journal of Solar Energy Engineering 105(1): 42-49.

Narasimhan, T. N. 2010. Thermal Conductivity Through the 19th Century. Physics Today 65: 36-41.

NRCS 2013. http://www.wcc.nrcs.usda.gov/scan/

Persson, C., and J. Claesson. 2005. Steady State Thermal Problem of Insulated Pipes Solved with the Multipole Method. Chalmers University of Technology.

Piechowski, M. 1996. A Ground Coupled Heat Pump System with Energy Storage. Ph.D. Dissertation. Melbourne University.

Piechowski, M. 1999. Heat and Mass Transfer Model of a Ground Heat Exchanger: Theoretical Development. International Journal of Energy Research 23(7): 571-588.

Saastamoinen, J. J. 2007. Unsteady State Temperature Fields in a Slab Induced by Line Sources. International Journal of Heat and Mass Transfer 50(3-4): 756-765.

Thomson, W. 1862. On the Reduction of Observations of Underground Temperature, with applications to Professor Forbes' Edinburgh Observations and the continued Calton Hill Series. Proceedings of the Royal Society of Edinburgh. IV: 342-346.

Xing, L., J. D. Spitler, and J. R. Cullin. 2012. Modeling of Foundation Heat Exchangers - Comparison of Numerical and Analytical Approaches. Building Simulation: An International Journal. 5(3): 267-279.

Xing, L. 2014. Estimations of Undisturbed Ground Temperatures Using Numerical and Analytical Modeling. Ph.D. Dissertation. Oklahoma State University.

Xing, L. and J.D. Spitler. 2016a. Prediction of undisturbed ground temperature using analytical and numerical modeling. Part I: Model development and experimental validation. Science and Technology for the Built Environment. DOI: 10.1080/23744731.2016.1258371. ISSN: 2374-474X.

Xing, L. and J.D. Spitler. 2016b. Prediction of undisturbed ground temperature using analytical and numerical modeling. Part II: Methodology for developing a world-wide dataset. Science and Technology for the Built Environment. DOI: 10.1080/23744731.2016.1262705. ISSN: 2374-474X.

Xing, L., J.D. Spitler and A. Bandyopadhyay. 2016. Prediction of undisturbed ground temperature using analytical and numerical modeling. Part III: Experimental validation of a world-wide dataset. Science and Technology for the Built Environment. DOI:10.1080/23744731.2016.1253978. ISSN: 2374-474X. 